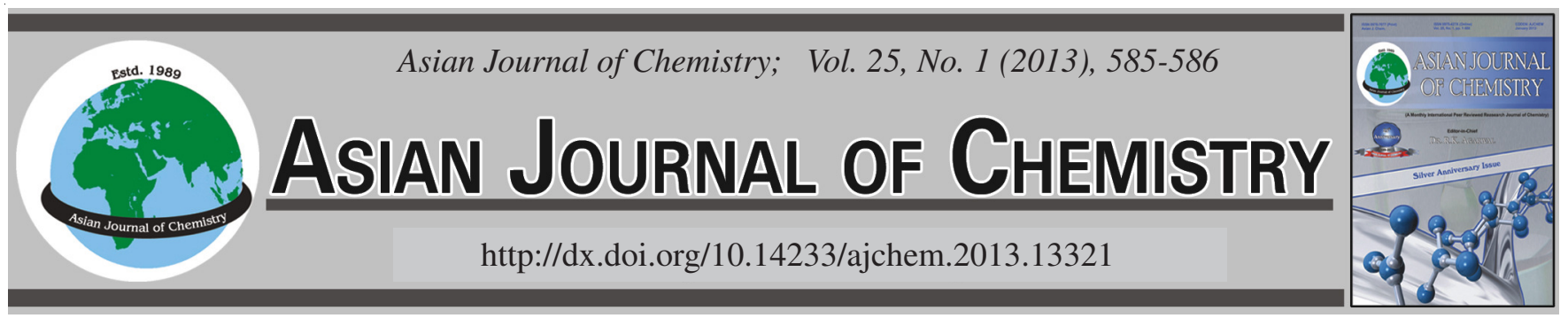

NOTE

\title{
Another New Alkaloid from Corydalis impatiens
}

\section{Ji Chang Li ${ }^{1,2}$, Yue Hua Lin ${ }^{1}$, Yong Hou ${ }^{1}$, Ping Li $^{1}$, Chun Tao Xu' and Gan Peng Li ${ }^{2}$,*}

${ }^{1}$ Zhongshan Polytechnic, Zhongshan 528404, P.R. China

${ }^{2}$ Key Laboratory of Chemistry in Ethnic-medicine Resources, School of Chemistry \& Biotechnology, Yunnan University of Nationalities, Kunming 650031, P.R. China

*Corresponding author: E-mail: ganpeng_li@sina.com

A new alkaloid, named impatien B (1) was isolated from the roots of Corydalis impatiens (Pall.) Fisch. The structure of the new compounds was established on the basis of spectroscopic data analysis, especially of their 2D NMR spectra.

Key Words: Corydalis impatiens, Isoindole alkaloids.

Corydalis impatiens (Pall.) Fisch grows in south China and is an important component in various prescriptions in traditional Chinese medicine ${ }^{1}$. The Corydalis plant has been demonstrated to possess many pharmacological activities, including antibacterial, antiviral and anticancer activities ${ }^{2}$. To the best of our knowledge, no study on the chemical constituents of the C. impatiens has hitherto been reported. As part of our studies of medicinal plants growing on the Yunnan Plateau, we did a careful phytochemical investigation on the roots of this plant. As a result, a new alkaloids was isolated and identified as impatien B (1).

The roots of $C$. impatiens were collected from Diqing area, Yunnan Province, China, in October 2005 and identified by Prof. Gan-Peng Li in Yunnan University of Nationalities.A voucher specimen was deposited in our laboratory of school of chemistry and biotechnology.

Extraction and isolation: The air-dried plant materials $(14 \mathrm{Kg})$ were ground, and extracted with $70 \% \mathrm{EtOH}$ under reflux. The filtered extract was combined and concentrated in vacuum at $40{ }^{\circ} \mathrm{C}$ to yield $\mathrm{EtOH}$ extract $(750 \mathrm{~g})$. The extract was dissolved in $2 \%$ hydrochloric acid. The filtrated $\mathrm{HCl}$ aqueous solution was defatted with ether and basified to $\mathrm{pH}=$ 10 with $10 \%$ aqueous ammonia and was extracted with chloroform to give total alkaloids (300 g). The chloroform soluble extract ( $30 \mathrm{~g}$ ) was repeated CC and Sephadex LH-20 to provide impatien B (1) (30 mg).

Compound 1 was determined to have the molecular formula $\mathrm{C}_{21} \mathrm{H}_{19} \mathrm{NO}_{6}$ based on high resolution HRESIMS ( $\mathrm{m} / \mathrm{z}$ $382.1291[\mathrm{M}+1]^{+}$, calcd 382.1290), yellow needles, m.p. 162-

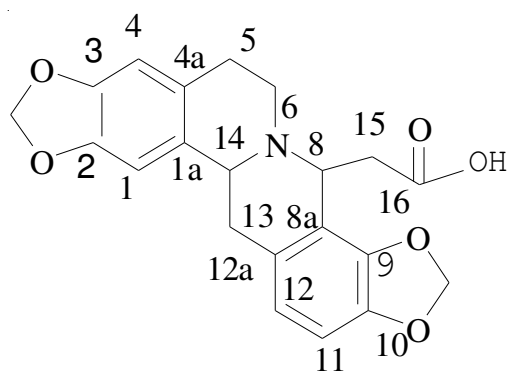

1

Fig. 1. Structures of compound $\mathbf{1}$

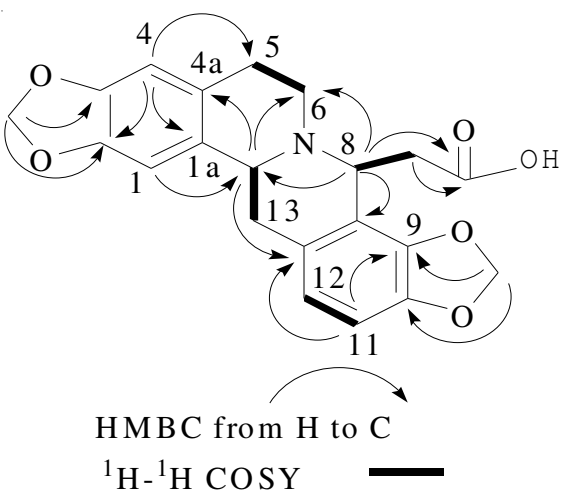

Fig. 2. Key HMBC and ${ }^{1} \mathrm{H}^{-}{ }^{-} \mathrm{H}$ COSY correlations of compound $\mathbf{1}$

$163{ }^{\circ} \mathrm{C}$. The UV spectrum of $\mathbf{1}$ showed absorption maxima at 264 (2.6) $\mathrm{nm}$ and the inspection of the NMR data revealed an protoberberine-type alkaloids ${ }^{3-5}$. The ${ }^{13} \mathrm{CNMR}$ and DEPT 
TABLE-1

NMR (300 Hz) DATA OF COMPOUND $1\left(\mathrm{CDCl}_{3}, \delta\right.$ ppm, $\left.J \mathrm{IN} \mathrm{Hz}\right)$

\begin{tabular}{cll}
\hline Compd. No. & \multicolumn{1}{c}{$\delta_{\mathrm{H}}$} & \multicolumn{1}{c}{$\delta_{\mathrm{C}}$} \\
\hline $\mathbf{1}$ & $6.74(1 \mathrm{H}, \mathrm{s})$ & $107.6(\mathrm{~d})$ \\
$\mathbf{1 a}$ & & $129.0(\mathrm{~s})$ \\
$\mathbf{2}$ & & $148.1(\mathrm{~s})$ \\
$\mathbf{3}$ & & $149.1(\mathrm{~s})$ \\
$\mathbf{4}$ & $6.67(1 \mathrm{H}, \mathrm{s})$ & $109.5(\mathrm{~d})$ \\
$\mathbf{4 a}$ & & $125.3(\mathrm{~s})$ \\
$\mathbf{5}$ & $2.98(2 \mathrm{H}, \mathrm{d}, J=5.0)$ & $28.1(\mathrm{t})$ \\
$\mathbf{6}$ & $3.15(2 \mathrm{H}, \mathrm{d}, J=5.0)$ & $45.7(\mathrm{t})$ \\
$\mathbf{8}$ & $4.70(1 \mathrm{H}, \mathrm{t}, J=5.0, J=15.9)$ & $59.1(\mathrm{~d})$ \\
$\mathbf{8 a}$ & & $115.3(\mathrm{~s})$ \\
$\mathbf{9}$ & & $145.3(\mathrm{~s})$ \\
$\mathbf{1 0}$ & & $147.5(\mathrm{~s})$ \\
$\mathbf{1 1}$ & $6.78(1 \mathrm{H}, \mathrm{d}, J=8.0)$ & $109.6(\mathrm{~d})$ \\
$\mathbf{1 2}$ & $6.70(1 \mathrm{H}, \mathrm{d}, J=8.0)$ & $122.9(\mathrm{~d})$ \\
$\mathbf{1 2 a}$ & & $125.7(\mathrm{~s})$ \\
$\mathbf{1 3}$ & $3.34(2 \mathrm{H}, \mathrm{d}, J=6.6)$ & $32.2(\mathrm{t})$ \\
$\mathbf{1 4}$ & $3.54(1 \mathrm{H}, \mathrm{d}, J=6.6)$ & $52.0(\mathrm{~d})$ \\
$\mathbf{1 5}$ & $2.79(2 \mathrm{H}, \mathrm{t}, J=5.0, J=15.9)$ & $36.7(\mathrm{t})$ \\
$\mathbf{1 6}$ & & $176.9(\mathrm{~s})$ \\
$-\mathrm{OCH}_{2} \mathrm{O}-$ & $6.00(2 \mathrm{H}, \mathrm{d})$ & $102.6(\mathrm{t})$ \\
$-\mathrm{OCH}_{2} \mathrm{O}-$ & $5.91(2 \mathrm{H}, \mathrm{d})$ & $103.2(\mathrm{t})$ \\
\hline
\end{tabular}

(Table-1) spectra of compound $\mathbf{1}$ showed twenty-one carbon signals including five methylene, six methine and nine quaternary carbons. The ${ }^{13} \mathrm{CNMR}$ signal at $\delta_{\mathrm{C}} 176.9(\mathrm{~s})$ revealed a carboxyl. The HMBC correlations from $\delta_{\mathrm{H}} 2.79(\mathrm{H}-15)$ to $\delta_{\mathrm{C}}$ $176.9(\mathrm{C}-16), \delta_{\mathrm{C}} 59.1(\mathrm{C}-8)$ and from $\delta_{\mathrm{H}} 4.70(\mathrm{H}-8)$ to $\delta_{\mathrm{C}} 115.3$ $(\mathrm{C}-8 \mathrm{a}), \delta_{\mathrm{C}} 45.7(\mathrm{C}-6), \delta_{\mathrm{C}} 36.7(\mathrm{C}-15), \delta_{\mathrm{C}} 176.9$ (C-16) indicated an carboxyl at $\mathrm{C}-8$, which also was supported by its IR data $\left(1718 \mathrm{~cm}^{-1}\right)$. There are four spin-spin systems (Fig. 2) of 1 established by COSY correlations, the first spin-spin system by two protons at $\delta_{\mathrm{H}} 2.98(2 \mathrm{H}, \mathrm{d}, J=5.0 \mathrm{~Hz}, \mathrm{H}-5)$ and $\delta_{\mathrm{H}} 3.15$ $(2 \mathrm{H}, \mathrm{d}, J=5.0 \mathrm{~Hz}, \mathrm{H}-6)$, the second spin-spin system by other two protons at $\delta_{\mathrm{H}} 4.70(1 \mathrm{H}, \mathrm{t}, J=5.0,15.9 \mathrm{~Hz}, \mathrm{H}-8)$ and $\delta_{\mathrm{H}}$ $2.79(2 \mathrm{H}, \mathrm{t}, J=5.0,15.9 \mathrm{~Hz}, \mathrm{H}-15)$, the third spin-spin system by other two protons at $\delta_{\mathrm{H}} 3.34(2 \mathrm{H}, \mathrm{d}, J=6.6 \mathrm{~Hz}, \mathrm{H}-13)$ and $\delta_{\mathrm{H}} 3.54(1 \mathrm{H}, \mathrm{d}, J=6.6 \mathrm{~Hz}, \mathrm{H}-14)$ and the fourth spin-spin system by two aromatic protons at $\delta_{\mathrm{H}} 6.78(1 \mathrm{H}, \mathrm{d}, J=8.0 \mathrm{~Hz}$, $\mathrm{H}-11)$ and $\delta_{\mathrm{H}} 6.70(1 \mathrm{H}, \mathrm{d}, J=8.0 \mathrm{~Hz}, \mathrm{H}-12)$. Based on those analyses, the structure of $\mathbf{1}$ (Fig. 1) was identified as impatien B.

\section{ACKNOWLEDGEMENTS}

This work was financially supported by the project of Key Project of Chinese Ministry of Education (No. 208132). The authors are grateful to the members of the staff of analytical group of Key Laboratory of Chemistry in Ethnic-medicine Resources, School of Chemistry \& Biotechnology, Yunnan University of Nationalities, for the measurements of all spectra.

\section{REFERENCES}

1. Z.Y. Wu, D.J. Yu and R. Lin, Flora Republicae Popularis Sinicae, 32, 344 (2004)

2. J.C. Li, X.H. Dong and J.W. Deng, J. Chin. Med. Mater, 33, 210 (2010).

3. A. Patra, C.T. Montgomery, A.J. Freyer, H. Guinaudeau, M. Shamma, B. Tantisewie and K. Pharadai Phytochemistry, 26, 547 (1987).

4. P.M.M. Pinho, M.M.M. Pinto, A. Kijjoa, K. Pharadai, J.G. Díaz and W. Herz, Phytochemistry, 31, 1403 (1992).

5. L. Grycová, J. Dostal and R. Marek, Phytochemistry, 68, 150 (2007). 